\title{
Photodermatosis secondary to hydroxyurea
}

\author{
Uday Yanamandra, Kamal Kant Sahu, Pankaj Malhotra, Subhash Varma
}

Haematology Unit, Department of Internal Medicine, PGIMER, Chandigarh, India

\section{Correspondence to}

Dr Uday Yanamandra, udayj2@gmail.com

Accepted 9 September 2014

\section{DESCRIPTION}

A middle aged Southeast-Asian man, recently diagnosed with chronic myeloid leukaemia (Philadelphia positive on FISH), was started on cytoreductive therapy with hydroxyurea due to high leucocyte count $(130000 / \mu \mathrm{L})$. The patient had no history of using any other drugs simultaneously or in the recent/remote past. He developed a clearly defined erythematous rash over only those areas of his body exposed to the sun. The rash progressed to confluent epidermal necrosis, denudation with peeling and minimal associated inflammation (figure 1). There was recovery with intact skin (figure 2) after 3 weeks of abstinence of the drug and after using sun blocking measures including sunscreen (SPF-30). He had no history of any idiopathic photodermatoses such as actinic prurigo, hydroa vacciniforme or chronic actinic dermatitis.

Features seen in photodermatosis secondary to drugs include: rash predominantly on skin-exposed areas, with clear definition between sun-exposed/ non-exposed areas, and temporal correlation rash from using the implicating drug. In our patient, clues to diagnosis were the presence of the above characteristics, sparing of the upper eye lids and resolution of rash with withdrawal of drug. Also, the presentation suggests photo-toxicity more than

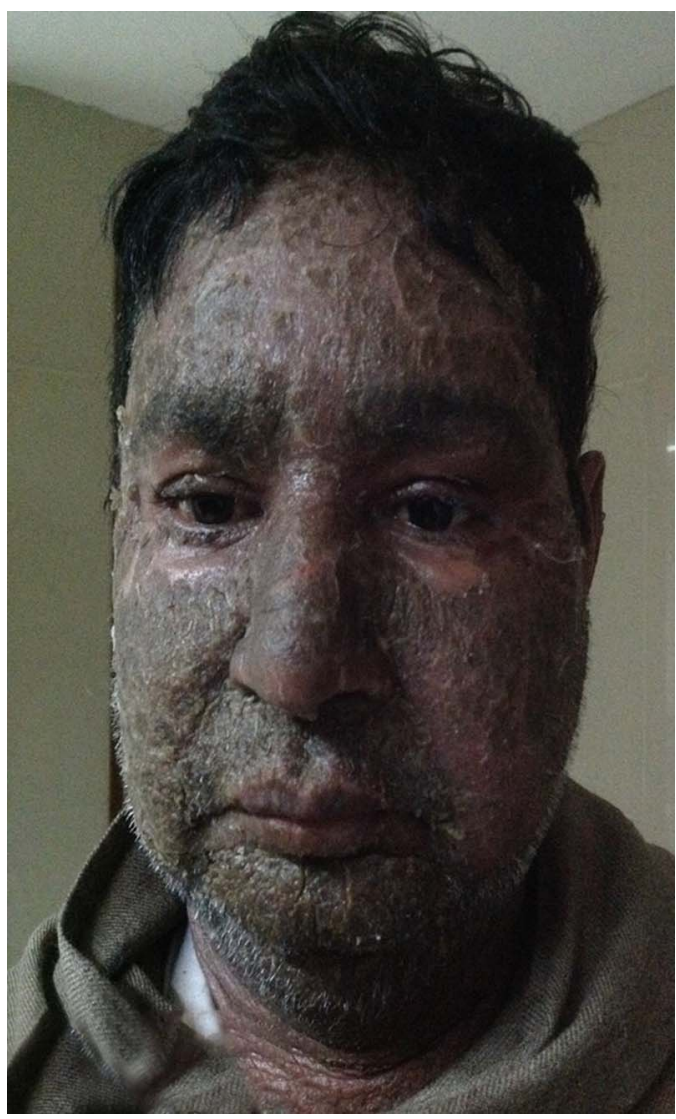

Figure 1 Skin lesions secondary to hydroxyurea.

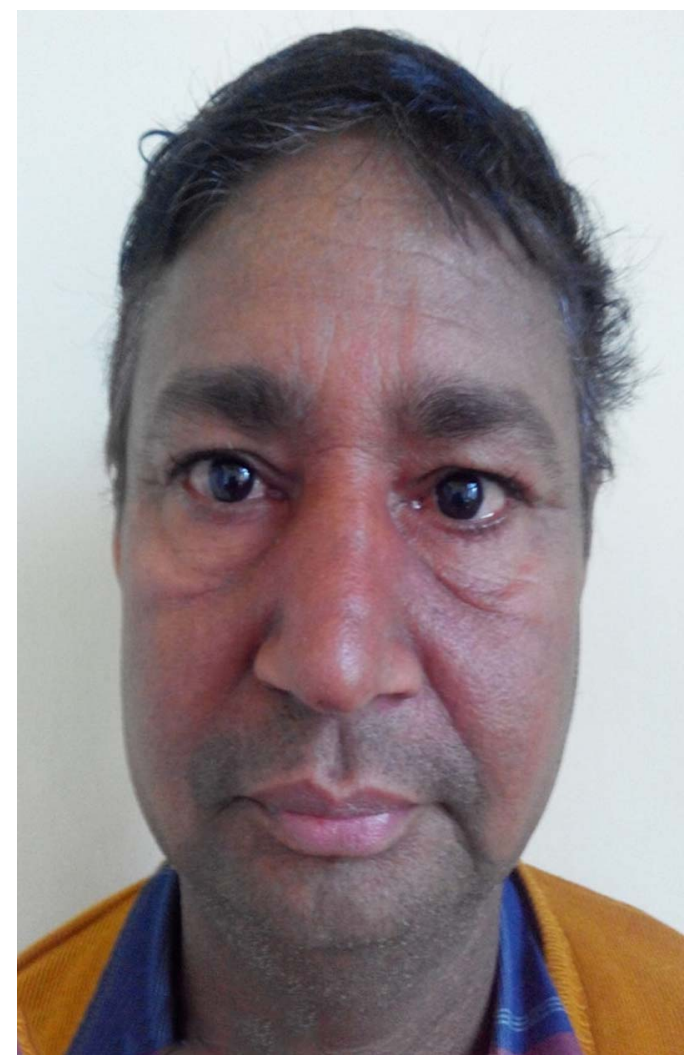

Figure 2 Resolution of skin lesions following abstinence.

photoallergy. In such cases if the usage of drug is mandatory then decreased sun exposure and sun protection with sunscreens can be tried.

Hydroxyurea (hydroxycarbamide) is associated with various dermatological syndromes such as alopaecia, facial erythaema, cutaneous vasculitic toxicities, skin atrophy and nail pigmentation. ${ }^{1}$ Prolonged usage of this drug is associated with dermatomyositis and dermatomyositis-like eruptions. $^{2}$ Photosensitivity is also occasionally reported with use of this drug. ${ }^{3}$

\section{Learning points}

- Hydroxyurea can lead to photodermatosis of a phototoxic type.

- Exposure to sun and the drug simultaneously should be avoided.

- Photodermatosis secondary to hydroxyurea should be differentiated from dermatomyositis-like eruptions.

Acknowledgements The authors acknowledge the contributions of Dr Shekhar Neema, Dermatologist, in providing his valuable comments. 
Competing interests None.

Patient consent Obtained.

Provenance and peer review Not commissioned; externally peer reviewed.
2 Senet P, Aractingi S, Porneuf $\mathrm{M}$, et al. Hydroxyurea-induced dermatomyositis-like eruption. Br J Dermatol 1995;133:455-9.

3 León-Mateos A, Zulaica A, Caeiro JL, et al. Photo-induced granulomatous eruption by hydroxyurea. J Eur Acad Dermatol Venereol 2007;21:1428-9.

\section{REFERENCES}

1 Antonioli E, Guglielmelli P, Pieri L, et al. AGIMM Investigators. Hydroxyurea-related toxicity in 3,411 patients with Ph'-negative MPN. Am J Hematol 2012;87:552-4.

Copyright 2014 BMJ Publishing Group. All rights reserved. For permission to reuse any of this content visit http://group.bmj.com/group/rights-licensing/permissions.

BMJ Case Report Fellows may re-use this article for personal use and teaching without any further permission.

Become a Fellow of BMJ Case Reports today and you can:

- Submit as many cases as you like

- Enjoy fast sympathetic peer review and rapid publication of accepted articles

- Access all the published articles

- Re-use any of the published material for personal use and teaching without further permission

For information on Institutional Fellowships contact consortiasales@bmjgroup.com

Visit casereports.bmj.com for more articles like this and to become a Fellow 